\title{
Integrating the 21st Century Character Values for Elementary School Students
}

\author{
Badrun Kartowagiran, Universitas Negeri Yogyakarta, Indonesia, kartowagiran@uny.ac.id, ORCHID: \\ 0000-0002-8536-5417
}

Syukrul Hamdi, Universitas Negeri Yogyakarta, Indonesia, syukrulhamdi@uny.ac.id, ORCHID:0000-00034809-1450

Edi Istiyono, Universitas Negeri Yogyakarta, Indonesia, edi_istiyono@uny.ac.id, ORCHID: 0000-0001-6034$142 X$

Ahmad Fauzi Mohd Ayub, Universiti Putra Malaysia, Malaysia, afmy@upm.edu.my, ORCHID: 0000-00024313-2922

Sintha Sih Dewanti, Universitas Negeri Yogyakarta \& UIN Sunan Kalijaga Yogyakarta, Indonesia, sinthasih.2018@student.uny.ac.id \& sintha.dewanti@uin-suka.ac.id, ORCHID:0000-0001-5966-1354

\begin{abstract}
This study aims to reveal the integration of character values needed by elementary school students to face the challenges of the 21st century. This study used the explanatory sequential mixed method design starting from quantitative research and then linked to qualitative research. A sample of 654 students and 100 elementary school teachers is established using the stratified random sampling technique based on district area, school status, and school accreditation category. The instrument measures six aspects of the character of the 21st century, namely mindfulness, curiosity, courage, resilience, ethics, and leadership. The results of the Multivariate Analysis of Variance show that there are significant differences in the integration of the character values of the 21st century in terms of the district area. Kulon Progo Regency is significantly higher in integration than other districts. The integration of the character values of the 21st century is carried out on three bases, namely class, school culture, and society. The positive impact of integration, namely: balanced cognitive abilities, sensitivity to the surrounding environment is built, self-confidence is formed, empathy is formed, a soul full of responsibility is built, and emotional intelligence is possessed.
\end{abstract}

Keywords: character value integration, elementary school, 21st century character values Received: 09.12.2020 Accepted: 24.01.2021 $\quad$ Published: 03.02.2021

\section{INTRODUCTION}

The technological revolution in the 21st century takes place quickly and occurs in all areas of human life (Ackerman \& Kanfer, 2020; Zervoudi, 2020). This has resulted in the emergence of a new order, new measures, and new needs that are different from those of the past, which must be responded and fulfilled by the national education as well as possible (Facer \& Sandford, 2010). Therefore, education must keep up with these changes in order to adapt to them (Demirel, 2009; Oke \& Fernandes, 2020). The pillars of Indonesia's national education need to be reorganized or transformed in a comprehensive and systemic manner so that education can further contribute to the pace and progress of the nation (Mappiasse, 2014; Ministry of Education and Culture, 2017; OECD, 2015). This can be started by putting back character as the spirit or the deepest dimension of national education side by side with intellectuality which is reflected in competence (Rindrayani, 2020; Sukasni \& Efendy, 2017). Education is obliged to be a means of character building, because without character, individuals will lose their originality and their presence in the society will cause losses and increase the complexity of life (Marini, 2017; Pala, 2011). Education that produces strong character and high competence will be able to meet various needs and overcome new challenges and demands (Zurqoni, Retnawati, Apino, \& Anazifa, 2018). Therefore, apart from intellectual development, student character development is very important in the Indonesian national education system.

Character education is an important element to be applied in a school environment that will support the education system in Indonesia, where this education has a function as a character and morale builder of students (the Republic of Indonesia, 2003; Zubaedi, 2011). It is intended to build a strong human figure who is not easily shaken in facing all existing problems. It is closely related to emotional intelligence which is one of the top ten skills needed in the 21st century (Gleason, 2018). The implementation of character education must pay attention to the right aspects and methods so that it can 
run in balance according to government programs (Dharma, Triatna, \& Permana, 2011; Marini, 2018). The number of cognitive-based subjects in the curriculum must be reduced, because if too much cognitive education will trigger violence and juvenile delinquency (Aprilia, 2014; Murthy \& Patriana, 2016). Learning patterns can also be improved by adding character education materials to hone affective abilities (Kamaruddin, 2012; Ratnaningsih, 2017).

Various concepts and frameworks for character education have been offered and applied in several countries. According to Lickona (1991) character is the inner character of an individual to respond to situations morally. Character has three interrelated parts, namely moral knowledge, moral feelings, and moral behavior. In other words, character refers to a set of cognitive, attitudes, motivations, behaviors, and skills (Parks \& Guay, 2009; Zurqoni et al., 2018). Character education is a national movement to make students ethical, responsible, and caring (NCDPI Character Education Consultant, 2006). Schools become agents to inculcate noble character values through learning and giving examples or models to students (Abdullah, Hudayana, Setiadi, Kutanegara, \& Indiyanto, 2019). Character is the universal human behavior values that cover all human activities, in relation to God, with himself, with fellow humans, and with the environment (Haniah, Aman, \& Setiawan, 2020; Marzuki, 2009).

Character development can refer to the character values developed by UNESCO, namely trustworthiness, respect, responsibility, fairness, caring, and citizenship (Zamroni, 2011). McElmeel (2002) offers seventeen character values to be instilled in students, namely "caring, confidence, courage, curiosity, flexibility, friendship, goalsetting, humility, humor, initiative, integrity, patience, perseverance, positive attitude, problem-solving, self-discipline, and teamwork". On the other hand, the Center for Curriculum Redesign (Bialik, Bogan, Fadel, \& Horvathova, 2015) identifies six important characters for the 21st century, namely mindfulness, curiosity, courage, resilience, ethics, and leadership. These character values need to be possessed by students through character building (Pala, 2011), namely the process of habituating good attitudes or morals to students, both in the learning process in class and in daily interactions outside the classroom and carried out by school community members in the school environment (Sabani \& Mihardi, 2015). Therefore, character habituation efforts must be done since early childhood and sustainably in education.

Primary school is the first formal education for students after early childhood education (Kokkalia, Drigas, Economou, \& Roussos, 2019). Primary schools are institutions that take part in making an important contribution to the nation (OECD, 2015). Primary school is the right place to instill character values in children (Agboola \& Tsai, 2012; Ratnaningsih, 2017). Elementary school age children easily imitate and follow the behavior of the other people in their environment. This is in line with the opinion of Wibowo (2012) that character and personality is very easily formed in the psychological characteristics of elementary school aged children. Character education is very important to inculcate in elementary school students who are in the golden age and development (Nelva, 2013). Everything students see, hear, do, and feel at primary school age will determine their future. This shows that education plays an important role in forming the quality of human resources. The formal education process in schools aims to develop a person with noble character (the Republic of Indonesia, 2003). Education is a process of internalizing culture into individuals and society that makes humans and societies civilized (Muslich, 2011). It makes it possible for the birth of the next generation with noble character.

\section{Research Problem}

The scope of character education is still very broad, so its implementation is not optimal. Only some aspects of character values can be inculcated but they are not measurable. Whereas each character has different meanings and values that are equally important for elementary school students, i.e. to build and equip the golden generation of Indonesia 2045 to face the dynamics of change in the future with the skills of the 21st century. The problem in this study is the absence of research on the integration of the 21st century character values for elementary school students.

\section{Research Focus}

There have been many studies on character education for elementary school students, but they have not focused on the character values needed in the 21st century. In addition, character values are not just inculcated in students, but character education needs to be developed and implemented by combining, relating, and integrating various elements of education in integrating character values. Therefore, this research begins with the reexamination of character values by focusing on the character values of the 21st century. The character values of the 21st century that have been formulated are then inculcated into elementary school students. Furthermore, it is necessary to take measurements to determine their 
integration in students. In addition, it is necessary to explore how educational actors integrate the character values of the 21st century with students, as well as the impact it brings about.

\section{METHODS}

\section{General Background of Research}

This research uses the Explanatory Sequential Mixed Method Design, where the research process starts from quantitative research that is linked to qualitative research, then conclusions are drawn. This research began with the development of an instrument for integrating the character values of the 21st century to obtain the constructs of the 21st century characters. Then an assessment instrument that has been proven valid and reliable is used to measure the integration of the character values of the 21st century in students. The quantitative research was concerned with the implementation and measurement of the integration of the 21st century character values in students, while the qualitative research dealt with an analysis of the integration of the 21st century character values carried out by educational actors, as well as the impact it brought about.

\section{Research Sample}

The population of this study is elementary school students of grades V and VI and elementary school teachers. The research sample consisted of 654 students and 100 teachers from 15 elementary schools spread over five different districts in the Special Region of Yogyakarta, Indonesia. The sample was established using the stratified random sampling technique, which paid attention to several levels, namely the districts (Yogyakarta City, Sleman, Bantul, Kulon Progo, and Gunung Kidul), school status (public and private), and accreditation categories (outstanding, very good, and good). This technique aims to ensure that the sample obtained will be evenly distributed at all levels and that it represents the character of all elements of a heterogeneous population.

\section{Research Instruments and Procedures}

The research instrument for the integration of 21st century character values is constructed based on the framework of the quality of the 21st century characters developed by the Center for Curriculum Redesign (Bialik et al., 2015). Based on the theoretical study, six aspects of the characters can be identified, which are translated into 20 indicators of the integration of character values as shown in Table 1.

Table 1. Indicators of the integration of principal character values of the 21st century

\begin{tabular}{|l|l|l|}
\hline $\begin{array}{l}\text { Principal } \\
\text { character of the } \\
\text { 21st century }\end{array}$ & $\begin{array}{l}\text { Character } \\
\text { aspects }\end{array}$ & Indicators of character value integration \\
\hline Mindfulness & $\begin{array}{l}\text { Spirituality } \\
\text { Compassion } \\
\text { Empathy } \\
\text { Sharing }\end{array}$ & $\begin{array}{l}\text { Inculcating a spiritual attitude } \\
\text { Giving affection to others } \\
\text { Inculcating a sense of empathy in teaching } \\
\text { Integrating the value of mutual help }\end{array}$ \\
\hline Curiosity & $\begin{array}{l}\text { Exploration } \\
\text { Motivation } \\
\text { Innovation }\end{array}$ & $\begin{array}{l}\text { Inculcating character of exploring } \\
\text { Integrating students' abilities to motivate their friends } \\
\text { Inculcating an innovative character }\end{array}$ \\
\hline Courage & $\begin{array}{l}\text { Bravery } \\
\text { Confidence } \\
\text { Optimism }\end{array}$ & $\begin{array}{l}\text { Integrating the character of bravery } \\
\text { Inculcating self-confidence in classroom learning } \\
\text { Inculcating the character of optimism }\end{array}$ \\
\hline Resilience & $\begin{array}{l}\text { Endurance } \\
\text { Self-control } \\
\text { Adaptability }\end{array}$ & $\begin{array}{l}\text { Inculcating the character of endurance } \\
\text { Developing students' ability to self-control } \\
\text { Adapting students to the learning environment }\end{array}$ \\
\hline Ethics & $\begin{array}{l}\text { Respect } \\
\text { Tolerance } \\
\text { Honesty }\end{array}$ & $\begin{array}{l}\text { Inculcating respect-for-others character } \\
\text { Inculcating an attitude of resistance during learning processes } \\
\text { Inculcating character of honesty in doing assignments and tests }\end{array}$ \\
\hline Leadership & $\begin{array}{l}\text { Citizenship } \\
\text { Responsibility } \\
\text { Selflessness } \\
\text { Consistency }\end{array}$ & $\begin{array}{l}\text { Cultivating a sense of love for the homeland } \\
\text { Educating students to have a sense of responsibility } \\
\text { Inculcating the character of unselfishness } \\
\text { Inculcating the character of consistency }\end{array}$ \\
\hline
\end{tabular}




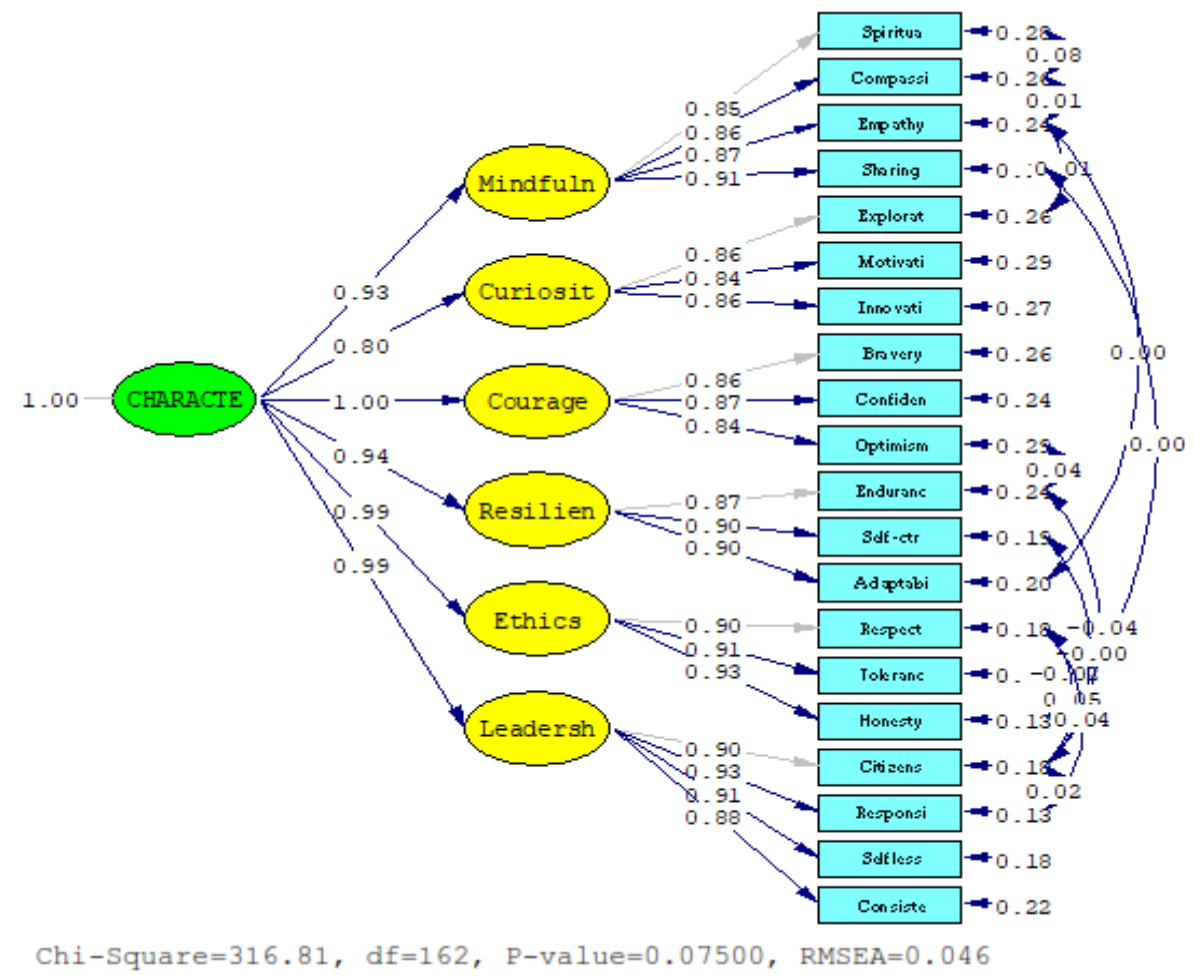

Figure 1. Standardized solution of theoretical construct of the 21st century character values

The construct validity of the theory of the 21st century character values is proven by the Confirmatory Factor Analysis (CFA). The output standardized solution after modification is presented in Figure 1. The CFA results show that the Chi-square is smaller than $2 \mathrm{df}(316.81<2 \times 162)$ (Jöreskog \& Sörbom, 1993), p-value $=0.075>0.05$ (Pedhazur, 1997), RSMEA $=0.046<0.08$ (Ferdinand, 2002), and the loading factor value of each item is higher than 0.3 , which means that all items are accepted (Hair, Black, Babin, \& Anderson, 2019). It can be concluded that the model for integrating the character values of the 21st century developed is fit (Nunnally \& Bernstein, 1994). The estimation of the reliability of the instrument used the Cronbach Alpha formula, resulting in the Cronbach Alpha coefficient of 0.980, which means the instrument is reliable (Feldt \& Brennan, 1989).

\section{Data Analysis}

The measurement results in the quantitative research were analyzed using the descriptive statistics and the testing of the average difference between the study sample areas used the Multivariate Analysis of Variance. This analysis is used to measure the effect of the independent variable (district area) with a categorical scale on several dependent variables (character values of the 21st century) with quantitative data scale at the same time. The qualitative data analysis was carried out by following the procedure of Miles and Huberman (1994) with steps including data collection, data reduction, data display, and conclusion drawing.

\section{RESULTS}

The results of the analysis of the integration of the character values of the 21st century in five districts obtained descriptive statistics as shown in Table 2, including the average integration of each aspect of the character values of the 21st century for each region. The overall data on the integration are shown in Figure 2. Of the five regions, the integration of the 21st century character values is not very different. The integration of the character values of the 21st century with the highest score is in Kulon Progo Regency and that with the lowest score is in Sleman Regency, while the integration of the highest character values in the ethics aspect is in the good category and the lowest in the curiosity aspect, which is in the sufficient category. In addition, Kulon Progo Regency is also the highest compared to other regions for every aspect of the character values of the 21st century. 
Table 2. Descriptive statistic of the integration of the 21st century character values in terms of region

\begin{tabular}{|l|l|l|l|l|l|}
\hline \multirow{2}{*}{ Region } & \multirow{N}{*}{} & \multicolumn{4}{|l|}{ Integration of the 21st century character values } \\
\cline { 3 - 6 } & & Lowest Score & Highest Score & Mean & Standard deviation \\
\hline Yogyakarta & 135 & 20 & 96 & 60.45 & 16.88 \\
\hline Sleman & 88 & 20 & 83 & 56.32 & 19.90 \\
\hline Bantul & 114 & 20 & 88 & 59.07 & 19.81 \\
\hline Kulon Progo & 133 & 20 & 100 & 67.23 & 20.27 \\
\hline Gunung Kidul & 184 & 20 & 81 & 58.23 & 22.24 \\
\hline Total & 654 & 20 & 100 & 60.41 & 20.35 \\
\hline
\end{tabular}

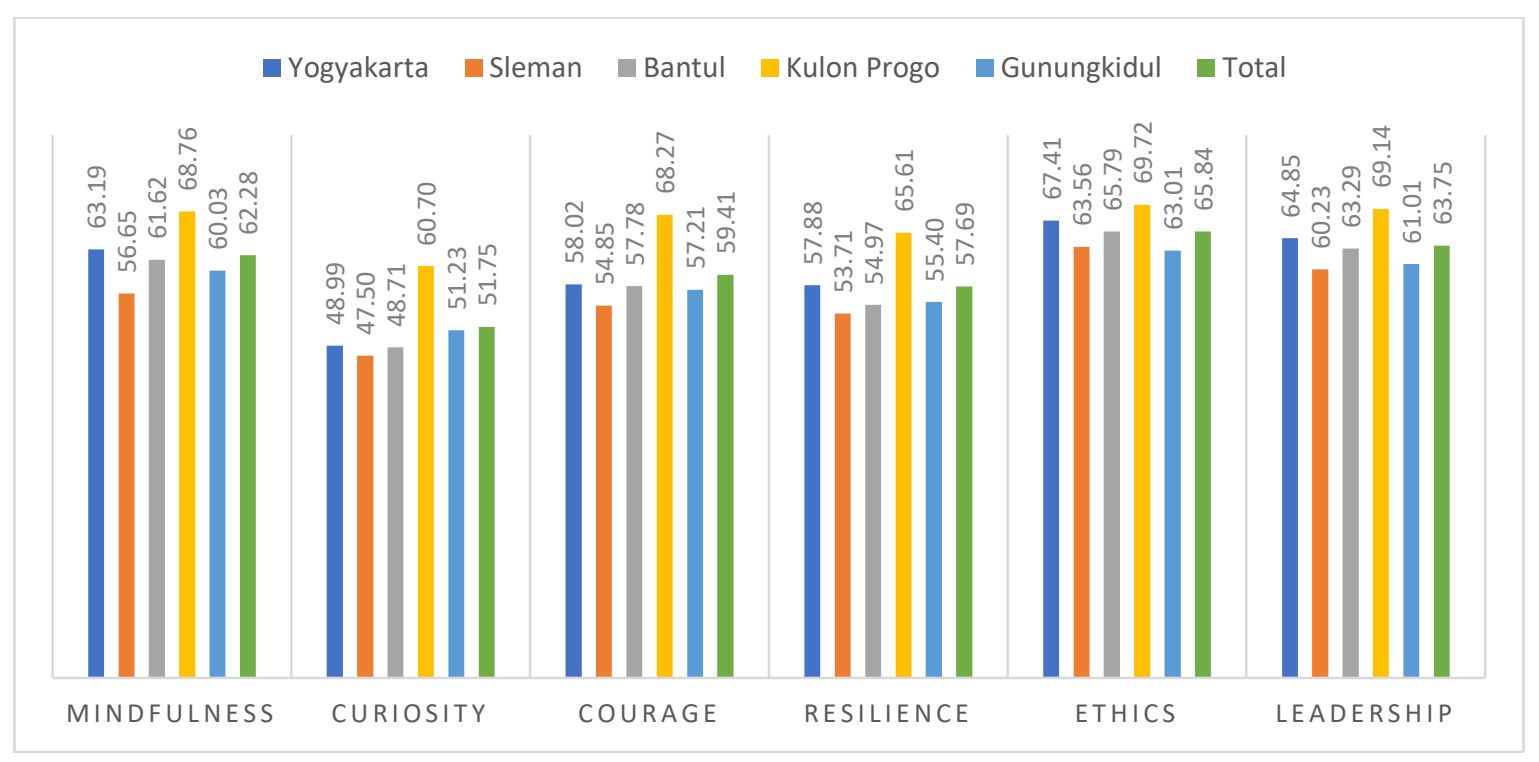

Figure 2. Mean score of each aspect of the 21st century character values of each region and the total

The basic requirement for conducting a Multivariate Analysis of Variance is that the dependent variables must be associated with each other or considered to belong to the same construct (Hair et al., 2019) as evidenced by CFA in Figure 1. The assumption of the dependent variable with multivariate normal distribution is described by a scatter-plot correlation between the Mahalanobis Distance variable from the 21st century character values variable with the qi variable (chi square value) as shown in Figure 3 . The correlation coefficient obtained is 0.968 , which shows a very high correlation coefficient, so it can be concluded that the data is normally multivariate distributed (Johnson \& Wichern, 2007).

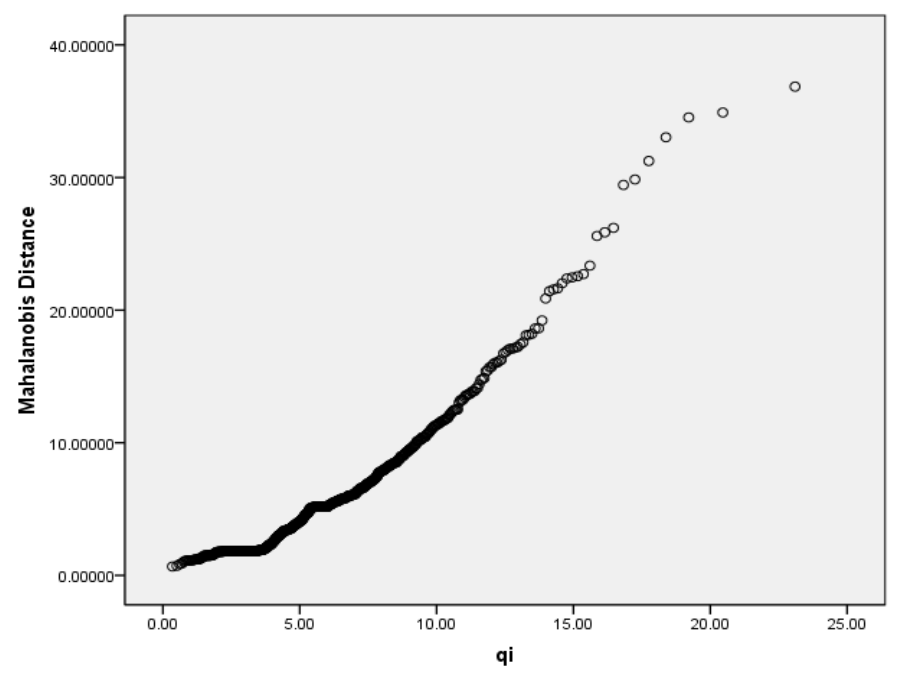

Figure 3. Scatter-plot of correlation between mahalanobis distance variable and qi variable 
Box's Test simultaneously testing the covariance equality between variables shows that the covariance between variables is not equivalent. Levene's Test examines the equality of variances in each specific variable, showing that the variance in each variable is not equivalent. However the homogeneity test is not an absolute prerequisite test for using ANOVA. This test adds information about the results of data analysis and considerations in conducting the Post-Hoc test using the Games-Howell (Johnson \& Wichern, 2007).

Table 3. Result of multivariate analysis of variance

\begin{tabular}{|c|c|c|c|c|c|c|c|c|}
\hline \multicolumn{9}{|c|}{ Multivariate Tests ${ }^{d}$} \\
\hline \multicolumn{2}{|l|}{ Effect } & Value & $\mathrm{F}$ & Hypothesis df & Error df & Sig. & $\begin{array}{l}\text { Noncent. } \\
\text { Parameter }\end{array}$ & $\begin{array}{l}\text { Observed } \\
\text { Power }\end{array}$ \\
\hline \multirow[t]{4}{*}{ Intercept } & Pillai's Trace & .910 & $1084.763^{a}$ & 6.000 & 644.000 & .000 & 6508.581 & 1.000 \\
\hline & Wilks' Lambda & .090 & $1084.763^{a}$ & 6.000 & 644.000 & .000 & 6508.581 & 1.000 \\
\hline & Hotelling's Trace & 10.106 & $1084.763^{a}$ & 6.000 & 644.000 & .000 & 6508.581 & 1.000 \\
\hline & Roy's Largest Root & 10.106 & $1084.763^{\mathrm{a}}$ & 6.000 & 644.000 & .000 & 6508.581 & 1.000 \\
\hline \multirow[t]{4}{*}{ District_Area } & Pillai's Trace & .100 & 2.777 & 24.000 & 2588.000 & .000 & 66.640 & 1.000 \\
\hline & Wilks' Lambda & .902 & 2.805 & 24.000 & 2247.858 & .000 & 58.595 & .999 \\
\hline & Hotelling's Trace & .106 & 2.826 & 24.000 & 2570.000 & .000 & 67.820 & 1.000 \\
\hline & Roy's Largest Root & .069 & $7.440^{\circ}$ & 6.000 & 647.000 & .000 & 44.643 & 1.000 \\
\hline \multicolumn{9}{|c|}{ a. Exact statistic } \\
\hline \multicolumn{9}{|c|}{ b. Computed using alpha $=.05$} \\
\hline \multicolumn{9}{|c|}{ c. The statistic is an upper bound on F that yields a lower bound on the significance level. } \\
\hline \multicolumn{9}{|c|}{ d. Design: Intercept + District_Area } \\
\hline
\end{tabular}

Based on Table 3 of the simultaneous comparison test, the $p$-value is $<0.05$, and this indicates that at the $95 \%$ confidence level there are significant differences in the six aspects of character values when viewed from district areas. Based on the Games-Howell test, the integration of the 21st century character values in Kulon Progo Regency was significantly higher than that in other districts for the aspects of curiosity, courage, and resilience. In the mindfulness and leadership aspects, the integration of the 21st century character values in Kulon Progo Regency is significantly higher than that of those in Sleman and Gunung Kidul Regencies, while in the ethics aspect, the integration of the 21st century character values in Kulon Progo Regency is significantly higher than that of those in Gunung Kidul Regency. This shows that Kulon Progo Regency has advantages and needs to be explored more qualitatively about the methods used in integrating the character values of the 21st century.

Based on the qualitative data analysis result, character values are developed and implemented by combining, relating, and integrating various elements of education. Integrating character values of the 21st century takes into account four principles, namely: 1) providing rational information; 2) formulating policies or regulations; 3) communicating the content and goal of character education; and 4) developing models, role models, and concrete examples of consistent positive characters, especially by teachers and all parts of the school environment. The integration of the character values of the 21st century was carried out on three bases as summarized in Table 4.

Table 4. Bases of integration of the 21st century character values

\begin{tabular}{|l|l|}
\hline $\begin{array}{l}\text { Basis } \\
\text { integration }\end{array}$ & Activities conducted \\
\hline Class & $\begin{array}{l}\text { Integration of the learning process through a thematic curriculum and } \\
\text { integrated into the subjects. Schools strengthen classroom management, select } \\
\text { methods, and evaluate learning. Schools develop local content according to local } \\
\text { needs. }\end{array}$ \\
\hline School Culture & $\begin{array}{l}\text { School activities emphasize the habituation of the main values in the daily lives } \\
\text { of students at school. Educators become role models in the educational } \\
\text { environment. The integration involves the entire educational ecosystem in } \\
\text { schools. The school develops and provides broad space for all student } \\
\text { potentials through co-curricular and extracurricular activities. Primary schools } \\
\text { empower school management and governance. School norms, regulations, and } \\
\text { traditions are considered in the implementation of every school activity. }\end{array}$ \\
\hline Community & $\begin{array}{l}\text { The roles of school committees and parents are strengthened as key education } \\
\text { stakeholders. This integration involves and empowers the potential of the } \\
\text { environment as learning resources, such as the presence and support of art and } \\
\text { cultural activists, community leaders, the business sector, and industrial sector. } \\
\text { Every activity that will be carried out is always synchronized with programs }\end{array}$ \\
\hline
\end{tabular}



government agencies, and the community at large.

\section{DISCUSSION AND CONCLUSIONS}

Character education that has so far been developed for elementary school students contains a very wide variety of character values. These character values include "religious, honest, tolerance, discipline, hard work, creative, independent, democratic, curiosity, national spirit, love for the country, respect for achievement, friendly/communicative, love peace, love to read, care for the environment, care. social, and responsibility". The wide range of character values results in a non-optimal inculcation of character values to elementary school students. Therefore, they need to be sorted, integrated, and focused on the character values of the 21st century in order to answer the challenges of the 21st century. Based on the study, six principal characters of the 21st century were obtained, namely mindfulness, curiosity, courage, resilience, ethics, and leadership.

Mindfulness is characterized as an initial thought in the form of an awareness and attraction to an ordinary and stable environment. Mace (2008) emphasizes mindfulness on awareness, or being fully aware of what is happening at this time. Therefore, individual awareness and attention is closely related to the nature of openness to experience (Baer, Smith, Hopkins, Krietemeyer, \& Toney, 2006; Brown \& Ryan, 2003; Lau, Bishop, Segal, Buis, Anderson, Carlson, \& Carmody, 2006; Ivtzan \& Conneely, 2009; Thompson \& Waltz, 2007), which is closely related to curiosity (Kashdan \& Steger, 2007). Individual curiosity to investigate new phenomena, challenge, or even something that confuses him (Izard, 1977; Kashdan, Rose, \& Fincham, 2004). Students will deliberately seek new and challenging experiences that will be able to expand their knowledge, skills, and goal-directed effort. Then, the students who have curiosity will enjoy and feel that seeking knowledge is fun (Kashdan \& Steger, 2007), as well as thinking about what remains to be found (Bryant \& Veroff, 2007; Wilson, Centerbar, Kermer, \& Gilbert, 2005).

The curiosity character possessed by students is related to their curiosity which in turn can lead to the emergence of openness to new things in the form of varied and challenging experiences. Curiosity is closely related to global life satisfaction, job satisfaction, and living a fun, interesting, and meaningful life (Brdar \& Kashdan, 2009; Shimai, Otake, Park, Peterson, \& Seligman, 2006). Peterson and Seligman (2004) state that individuals who have curiosity will actively seek information and feel satisfied if they succeed in obtaining answers to various questions. Students who have high curiosity tend to look for new and challenging events that lead to participation in meaning-oriented behavior in their lives. Student curiosity has a high correlation with intrinsic motivation (Cacioppo, Petty, Feinstein, Jarvis, \& Blair, 1996), and behavior that changes motivation (Reiss, 2004).

Courage includes bravery, confidence, and optimism. According to Peterson and Seligman (2004) courage includes bravery, persistence, integrity, and vitality. Courage involves a strong urge to achieve a goal. Even though there are obstacles, both external and internal obstacles, individuals are still motivated to strive to achieve goals. The result of the research by Birden (2020) revealed that emotional social learning can significantly increase students' courage and self-confidence. Children with strong character will grow up to be superior adolescents and be proud of being physically healthy, emotionally stable, and intellectually well developed.

Individual resilience has several characteristics that enable students to succeed in facing difficulties, such as: emotional regulation, stress tolerance, flexibility and adaptability, having good relationships with others, and having self-control (Connor \& Davidson, 2003; Reivich \& Shatte, 2002). Resilience is the ability to cope and survive through stressful situations and can also be seen as adaptive behavior (Clinton, 2008). Furthermore, Clinton (2008) explains that resilience refers to doing well despite difficulties. Associated behavior is not only part of a person's personality, but can be encouraged through personal and social development.

The ethical characters possessed by elementary school students such as mutual respect among them, tolerance, honesty and love for the country have been well integrated. The inculcation of ethical values is a very important part of education. Through character education, students will optimize ethical behavior, so that they will be disciplined in various ways (Agboola \& Tsai, 2012). Prasad (2019) states that ethics is a fundamental basis in life, so ethics needs to be integrated in every teaching, especially the development of technology and information life. Students who develop by considering ethical values tend to have better personalities (Machin, 2014; Richmond, 2001). Those who have high ethics will also have leadership skills to influence, direct, motivate and supervise other students in completing planned tasks.

Leadership is one of the principal characters of the 21 st century with indicators including responsibility, independence, and consistency (Bialik et al., 2015; Cacioppo et al., 1996). Leadership development in students is an integral part of the positive impact on the community and individual 
student growth (Ingleton, 2013). Leadership development and education carried out by educators will help students to understand their surroundings and encourage students to make changes. Therefore, leadership is a big responsibility for the education system which is faced with global challenges (Bowman, 2014). These global challenges include self-interest, immodesty, greed, bigotry, and violent extremism. Leadership cannot continue to be treated as a paradigm of the dictatorship of the past that only certain students can enter (Van Velsor \& Wright, 2012).

The positive impact of integrating the character values of the 21st century is that cognitive abilities become balanced, sensitivity to the surrounding environment is built, self-confidence is formed, empathy is formed, a spirit full of responsibility is built, and emotional intelligence is possessed. The implementation of character education can be carried out both inside and outside schools. Educational institutions are a strategic facility in the character building of the nation because they have structures, systems and devices that are scattered throughout Indonesia. School is something that plays an important role in preparing student life skills, both academically and non-academically (Johansson, Brownlee, CobbMoore, Boulton-Lewis, Walker, \& Ailwood, 2011). Character education needs to be instilled as early as possible and on an ongoing basis so that building or developing good character in children runs well. This is in line with Suwandayani and Isbadrianingtyas (2017) who explain that character education must be a compulsory teaching starting from elementary school because childhood or what psychologists call the golden age, is proven to greatly determine children's ability to develop their potential.

Character education that is inculcated in children from an early age will have an impact when they grow up. Similar to learning, through cultivating character there will be long-lasting changes in behavior, or in the capacity to behave in a certain way, resulting from practice or other forms of experience (Schunk, 2012). This is in line with the opinion of Haylock and Thangata (2007) that learning is a process in which a student organizes his experiences, summarizes something from a number of examples that have something in common, and uses it with one concept name for all that is related. The inculcation of character is carried out by the teacher, such as by integrating character values into the learning content, using teacher exemplary as a model or example for students, by accustoming to a school environment that has good character, by habituating all school members to behave in accordance with character values developed as role models for students, and most importantly through the development of school culture to support the success of character education. This shows that the role of teachers in the demands of the 21st century will be greater (Ghorbani, Jafari, \& Sharifian, 2018; Van Hong, Tuyen, \& Luong, 2018). A teacher must be equipped with a positive attitude toward professionalism, have insight into the subject matter being taught, and have a personality that can be emulated by students (Arisman, Getter, \& Nuryamin, 2018). Teachers and parents play an important role in strengthening the character values of the 21st century (Anwar, Saregar, Hasanah, \& Widayanti, 2018).

The integration of the character values of the 21st century within the learning framework of the 21st century requires students to have knowledge, skills, and capabilities in the fields of technology and information, innovation, and skills for life and careers (P21, 2015; Frydenberg, 2015). Pinto and Escudeiro (2014) state that "students are required to have communication skills, critical and creative thinking, information/ digital literacy, inquiry-reasoning skills, interpersonal skills, multiculturalmultilingual literacy, problem-solving, and technology skills". Therefore, the integration of the character values of the 21st century still needs to be a common concern in the school environment, family, and society. Integrating the character values of the 21st century can be done through: 1) integrating classroom activities, outside the classroom at school, and outside of school (community/ peer groups); 2) integration of intra-curricular, co-curricular, and extracurricular activities; and 3) simultaneous involvement of school community members, families and communities. Furthermore, it is necessary to deepen and expand the character values of the 21st century through: 1) additional and intensifying activities oriented towards the development of student character; 2) addition and exposure of student learning activities; and 3) rearrangement of student learning time at school or outside of school. After integration, deepening, and expanding is carried out, it is necessary to carry out an adjustment in the form of adjusting the main duties of teachers, school-based management, and the functions of the school committee with the needs of character education.

\section{REFERENCES}

Ackerman, P. L., \& Kanfer, R. (2020). Work in the 21st century: New directions for aging and adult development. American Psychologist, 75(4), 486-498.

Agboola, A., \& Tsai, K. C. (2012). Bring character education into classroom. European Journal of Educational Research, 1(2), 163-170. 
Anwar, C., Saregar, A., Hasanah, U., \& Widayanti, W. (2018). The Effectiveness of Islamic Religious Education in the Universities: The Effects on the Students' Characters in the Era of Industry 4.0. Tadris: Jurnal Keguruan Dan Ilmu Tarbiyah, 3(1), 77-87.

Aprilia, T. L. (2014). Developing PGSD students character through experience learning theory, Procedia Social and Behavioral Sciences, 123, 189-195.

Arisman, A., Getteng, A. R., \& Nuryamin, N. (2018). Pengaruh kompetensi kepribadian guru terhadap motivasi belajar peserta didik MTsN 2 Bone Kabupaten Bone. Jurnal Dirkursus Islam, 6(3), 418443.

Baer, R. A., Smith, G. T., Hopkins, J., Krietemeyer, J., \& Toney, L. (2006). Using self-report assessment methods to explore facets of mindfulness. Assessment, 1, 27-45.

Bialik, M., Bogan, M., Fadel, C., \& Horvathova, M. (2015). Character education for the 21st century: What should students learn? Center for Curriculum Redesign.

Birden, E. M. (2020). Courage in the classroom: The impact of social emotional learning on student perceptions of courage. Education Dissertations, 91

Bowman, R. F. (2014). Learning leadership skills in high school. The Clearing House: A Journal of Educational Strategies, Issues and Ideas, 87(2), 59-63.

Brdar, I., \& Kashdan, T. B. (2009). Strengths and well-being in Croatia. Unpublished raw data.

Brown, K. W., \& Ryan, R. M. (2003). The benefits of being present: Mindfulness and its role in psychological wellbeing. Journal of Personality and Social Psychology, 84, 822-848.

Bryant, F. B., \& Veroff, J. (2007). Savoring: A new model of positive experience. Mahwah, NJ: Erlbaum.

Cacioppo, J. T., Petty, R. E., Feinstein, J. A., Jarvis, W., \& Blair, G. (1996). Dispositional differences in cognitive motivation: The life and times of individuals varying in need for cognition. Psychological Bulletin, 119, 197-253.

Clinton, J. (2008). Resilience and Recovery. International Journal of Children's Spirituality, 13(3), 213-222.

Connor, K.M., \& Davidson, J.R.T. (2003). Development of a New Resilience Scale: The Connor-Davidson Resilience Scale (CD-RISC), Depression and Anxiety, 18, 76-82.

Demirel, M. (2009). Lifelong learning and schools in the twenty-first century. Procedia - Social and Behavioral Sciences, 1, 1709-1716.

Dharma, K., Triatna. C., \& Permana, J. (2011). Pendidikan karakter: Kajian teori dan praktek di sekolah. Bandung: PT Remaja Rosdakarya.

Facer, K., \& Sandford, R. (2010). The next 25 years?: Future scenarios and future directions for education and technology. Journal of Computer Assisted Learning, 26, 74-93.

Feldt, L. S., \& Brennan, R. (1989). Reliability. In R. L. Linn (Ed), Educational measurement (3rd ed.). New York: Macmillan.

Ferdinand, A., (2002). Structural equation modeling dalam penelitian manajemen. Edisi Kedua. Semarang: Badan Penerbit Undip.

Frydenberg, M., \& Andone, D. (2011). Learning for 21st century skills. Pergamon Press, Ltd.

Ghorbani, S., Jafari, S. E. M., \& Sharifian, F. (2018). Learning to be: Teachers' competences and practical solutions: A step towards sustainable development. Journal of Teacher Education for Sustainability, 20(1), 20-45.

Gleason, N. W. (2018). Higher education in the era of the fourth industrial revolution. Springer Published.

Hair, J. F., Black, W. C., Babin, B. J., \& Anderson, R. E. (2019). Multivariate Data Analysis. (8 ${ }^{\text {th }}$ Ed.). PerasonPrentice Hall.

Haylock, D., \& Thangata, F. (2007). Key concept in teaching primary mathematics. London: SAGE Publication.

Hurlock, E. B. (1972). Child Development (McGraw-Hill series in psychology). McGraw-Hill Education.

Ingleton, T. (2013). College student leadership development: Transformational leadership as a theoretical foundation. International Journal of Academic Research in Business and Social Sciences, 3(7), 219229.

Ivtzan, I., \& Conneely, R. (2009). Androgyny in the mirror of self-actualisation and spiritual health. The Open Psychology Journal, 2, 58-70.

Johansson, E., Brownlee, J., Cobb-Moore, C., Boulton-Lewis, G., Walker, S., \& Ailwood, J., (2011) Practices for teaching moral values in the early years: A call for a pedagogy of participation. Education, Citizenship and Social Justice, 6(2), 109-124.

Johnson, R. A., \& Wichern, D. W. (2007). Applied Multivariate Statistical Analysis. New Jersey: Prentice Hall. Jöreskog, K. G., \& Sörbom, D. (1993). LISREL 8: Structural equation modeling with the SIMPLIS command language. Chicago: Scientific Software International.

Kamarudin, S. A. (2012). Character Education and students social behavior. Journal of Education and Learning, 6(4), 223-230. 
Kashdan, T. B., Rose, P., \& Fincham, F. D. (2004). Curiosity and exploration: Facilitating positive subjective experiences and personal growth opportunities. Journal of Personality Assessment, 82, 291-305.

Kashdan, T. B., \& Steger, M. F. (2007). Curiosity and pathways to well-being and meaning in life: Traits, states and everyday behaviours. Motivation and Emotion, 31, 159-173.

Lau, M. A., Bishop, S. R., Segal, Z. V., Buis, T., Anderson, N. D., Carlson, L., \& Carmody, J. (2006). The Toronto mindfulness scale: Development and validation. Journal of Clinical Psychology, 62(12), 14451467.

Lickona. T. (1991). Educating for character: How our school can teach respect and responsibility. New York: Bantam Books.

Machin, A. 2014. Implementasi pendekatan saintifik, penanaman karakter dan konservasi pada pembelajaran materi pertumbuhan. Jurnal Pendidikan IPA Indonesia, 3(1), 28-35.

Mace, C. (2008). Mindfulness and mental health: Therapy, theory and science. Routledge/Taylor \& Francis Group.

Mappiasse, S. (2014). Education reform in Indonesia: Limits of neoliberalism in a weak state. UMI Dissertation Publishing.

Marini, A. (2017). Character building through teaching learning process: Lesson in Indonesia. International Journal of Sciences and Research, 73(5), 177-182.

Marini, A. (2018). Implementation of character building at elementary schools: Cases of Indonesia. Proceeding International Conference on University and Intellectual Culture, 1(1), 60-71.

Marzuki. (2009). Prinsip Dasar Akhlak Mulia: Pengantar Studi Konsep-konsep Dasar Etika dalam Islam. Yogyakarta: Debut Wahana Press-FISE UNY.

McElmeel, S. L. (2002). Character education: A book guide for teachers, librarians, and parents. Colorado: Libraries Unlimited.

Miles, M. B., \& Huberman, A. M. (1994). Qualitative data analysis: An expanded sourcebook. New York: Sage publication.

Ministry of Education and Culture. (2017). Konsep dan pedoman penguatan pendidikan karakter tingkat sekolah dasar dan sekolah menengah pertama. Jakarta: Kementerian Pendidikan dan Kebudayaan.

Murthy, M. P., \& Patriana, R. (2016). The significance of environmental contents in character education for quality of life. Procedia - Social and Behavioral Sciences, 222, 244-252.

Muslich, M. 2011. Pendidikan karakter menjawab tantangan kritis multidimensional. Jakarta: PT Bumi Aksara.

NCDPI Character Education Consultant. (2006). Character education: Informational handbook and guide for support and implementation of the student citizen act of 2001. North Carolina: Public Schools of North Carolina.

Nelva, R. (2014). Developing responsibility character for university student in ECE through project method, Procedia - Social and Behavioral Sciences, 123, 170-174.

Nunnally, J. C., \& Bernstein, I. H. (1994). Psychometric theory. McGraw-Hill Publishing.

OECD/Asian Development Bank. (2015). Education in Indonesia: Rising to the challenge, OECD Publishing, Paris. http://dx.doi.org/10.1787/9789264230750-en

Oke, A. \& Fernandes, F. A. P. (2020). Innovations in Teaching and Learning: Exploring the Perceptions of the Education Sector on the $4^{\text {th }}$ Industrial Revolution (4IR). Journal of Open Innovation: Technology, Market, and Complexity, 6(31).

P21 (Partnership for 21st century learning). (2015). Framework for 21st Century Learning.

Pala, A. (2011). The need for character education. International Journal of Social Sciences and Humanity Studies, 3(2), 23-32.

Pedhazur, E. J. (1997). Multiple regression in behavioral research (3th Ed.). CBS College Publishing.

Peterson, C., \& Seligman, M. E. P. (2004). Character strengths and virtues: A handbook of classification. Oxford University Press.

Pinto, A., \& Escudeiro, P. (2014). The use of scratch for the development of 21st century learning skills in ICT. Conference on Information Systems and Technologies (CISTI). Barcelona:IEEE.

Prasad, Leela (2019). Ethical resonance. Journal of Religious Ethics, 47(2), 394-415.

Ratnaningsih, S. (2017). Character education in primary school students prepare to face challenges of the 21st century. Advances in Social Science, Education and Humanities Research, 84.

Reiss, S. (2004). Multifaceted nature of intrinsic motivation: The theory of 16 basic desires. Review of General Psychology, 8, 179-193.

Reivich, K. \& Shatte, A. (2002). The resilience factor: 7 keys to finding your inner strength and overcoming life's hurdles. Broadway Books. 
Republic of Indonesia (2003). Undang-Undang Nomor 20 Tahun 2003 tentang Sistem Pendidikan Nasional [Law Number 20 of 2003 concerning the National Education System]. Jakarta, Indonesia.

Richmond, K. A. 2001. Ethical reasoning, Machiavellian behavior, and gender: The impact on accounting students' ethical decision making. Doctoral dissertation. Virginia Polytechnic Institute and State University.

Rindrayani, S. R. (2020). The implementation of character education in Indonesia high school curriculum program. Universal Journal of Educational Research, 8(1), 304-312.

Sabani, D. \& Mihardi, D. (2015). Improved characters and student learning outcomes through development of character education based general physics learning model. Journal of Education and Practice, 6(21), 162-171.

Schunk, D. H. (2012). Lerning theories (6 ${ }^{\text {th }}$ d.). Pearson Education Inc.

Shimai, S., Otake, K., Park, N., Peterson, C., \& Seligman, M. E. P. (2006). Convergence of character strengths in American and Japanese young adults. Journal of Happiness Studies, 7, 311-322.

Sukasni. A. \& Efendy, H. (2017). The problematic of education system in Indonesia and reform agenda. International Journal of Education, 9(3), 183-199.

Suwandayani, B. I., \& Isbadrianingtyas, N. (2017). Peran budaya sekolah dalam pembentukan karakter anak sekolah dasar. SENASGABUD, 34-41.

Thompson, B. L., \& Waltz, J. (2007). Everyday mindfulness and mindfulness meditation: Overlapping constructs or not? Personality and Individual Differences, 43, 1875-1885.

Van Hong, B., Tuyen, T., \& Luong, N. T. (2018). Teaching capacity of technology teachers: applying in the training program of technology teacher in Vietnam. American Journal of Educational Research, 6(12), 1662-1667.

Van Velsor, E., \& Wright, J. (2012). Expanding the leadership equation developing next-generation leader. ERIC: Center for Creative Leadership White Paper.

Wibowo, A. (2012). Pendidikan karakter: Strategi membangun karakter bangsa berperadaban. Yogyakarta: Pustaka Belajar.

Wilson, T. D., Centerbar, D. B., Kermer, D. A., \& Gilbert, D. T. (2005). The Pleasures of Uncertainty: Prolonging Positive Moods in Ways People Do Not Anticipate. Journal of Personality and Social Psychology, 88(1), 5-21.

Zamroni. (2011). Strategi dan model implementasi pendidikan karakter di sekolah. In D. Zuchdi (Ed.). Pendidikan karakter dalam perspektif teori dan praktik. UNY Press.

Zervoudi, E. K. (2020). Fourth Industrial Revolution: Opportunities, Challenges, and Proposed Policies. In A. Grau, \& Z. Wang, Industrial Robotics - New Paradigms.

Zubaedi. (2011), Desain Pendidikan Karakter: Konsep dan Aplikasinya dalam Lembaga Pendidikan. Jakarta: Kencana.

Zurqoni, Retnawati, R., Apino, E., \& Anazifa, R. D. (2018). Impact of character education implementation: A goal-free evaluation. Problems of Education in the 21 ${ }^{\text {st }}$ Century, 76(6), 881-899. 